
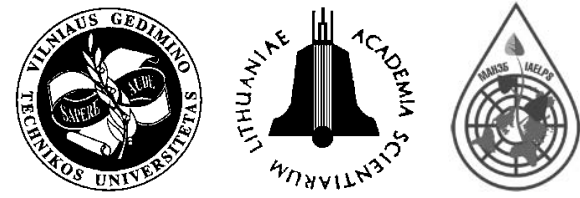

\title{
MODELLING EXTREME PRECIPITATION IN HAZARDOUS MOUNTAINOUS AREAS. CONTRIBUTION TO LANDSCAPE PLANNING AND ENVIRONMENTAL MANAGEMENT
}

\author{
Paulo Pereira $^{1}$, Marc Oliva ${ }^{2}$, Edita Baltrènaite ${ }^{3}$ \\ ${ }^{1}$ Mediterranean Environmental Research Group (GRAM), Dept of Physical Geography and \\ Regional Geographic Analysis, University of Barcelona, Montalegre, 6, 08001 Barcelona, Spain \\ ${ }^{1,3}$ Dept of Environmental Protection, Vilnius Gediminas Technical University, \\ Sauletekio al. 11, LT-10223 Vilnius, Lithuania \\ ${ }^{2}$ Landscape Research and Mediterranean Paleoenvironmental Research Group, Dept of Physical Geography \\ and Regional Geographic Analysis, University of Barcelona, Montalegre, 6, 08001 Barcelona, Spain \\ ${ }^{2}$ Centro de Estudos Geográficos, University of Lisbon, Alameda da Universidade, \\ 1600-214 Lisboa, Portugal \\ E-mail: ${ }^{1}$ pereiraub@gmail.com (corresponding author) \\ Submitted 23 Nov. 2009; accepted 14 Jun. 2010
}

\begin{abstract}
Extreme precipitation episodes are very common in Mediterranean area and can lead to serious and catastrophic environmental hazards. They have special incidence during autumn months, September, October and November (SON) with important impacts on society, leading frequently to significant economic losses and mortality. These events have special impact in mountainous areas where steep slopes enhance the effects of extreme precipitation. In mountainous areas rain gauge stations are sparse and normally in lower amount. Due to these reasons it is very important to map with higher accuracy the distribution of extreme precipitation. Also, in mountainous environments precipitation patterns can change in small distances that make the prediction more difficult, but also more important. A better prediction of areas with higher values of extreme precipitation will contribute to a better land use planning and avoid the effects of flash floods, landslides and soil erosion recognized as environmental problems. The aim of this paper is testing several well-known interpolation methods, Inverse Distance Weight (IDW) with weighs of 1, 2, 3, 4 and 5, Local Polynomial (LP) with order 1 and 2, Radial Basis Methods (RBS), particularly Spline With Tension (SPT) and Thin Plate Spline (TPS), and Kriging techniques, Ordinary Kriging $(\mathrm{OK})$ and Ordinary CoKriging $(\mathrm{COK})$ in order to identify the less-biased method to interpolate extreme precipitation calculated from the $95^{\text {th }}$ percentile (P95) of SON precipitation in a mountainous area located in Portugal.

The results show that extreme precipitation increases with the altitude and there are important differences between stations located at higher and lower altitudes. This relation is observed in the omni-directional semi-variograms calculated where we identified two major P95 areas coincident with higher elevations. The first one occurred at $12.19 \mathrm{~km}$ and the second at $23.57 \mathrm{~km}$. The higher values of P95 are identified at Southeast and Northeast. In contrast, the lower P95 values are identified at Northwest due to lower altitudes and in the Northeast corner as a consequence of rain shadow effect. Prediction with precision of precipitation patterns in mountainous areas is difficult due to lack of data and the complex effect of topography in rainfall, however, it is of major importance in order to identify vulnerable areas. The findings observed in this study are a fundamental contribution to landscape planning and environmental management in areas with higher occurrence and vulnerability to extreme precipitation.
\end{abstract}

Keywords: extreme precipitation, environmental hazards, Mediterranean area, September, October, November (SON), mountainous areas, interpolation methods, landscape planning and environmental management.

\section{Introduction}

Mediterranean climate is located in the transitional zone between the humid western and central European domain and the arid North African desert belt. It is characterized by alternating circulation regimes connected to dry and wet seasons throughout the year (Dünkeloh and Jacobeit 2003). One of the main peculiarities of this type of climate is the spatial and temporal irregularity of the precipitation, as several studies pointed out (Tildes Gomes 1998; Trigo and DaCamara 2000; Brunetti et al. 2001; Santos et al. 2005; Fragoso and Tildes Gomes 2008; Pa- van et al. 2008; among others). In Europe autumn, winter and spring precipitation depends mainly of the North Atlantic Oscillation (NAO) dynamic. NAO is a large scale atmospheric circulation and is characterized by the pressure difference between two active centers of the atmospheric pressure, the Icelandic low located at North and the Subtropical high located at South. NAO positive index is characterized by lower than normal surface pressure over the Icelandic region and higher than normal surface over tropical Atlantic together yield a larger than normal meridional pressure, generating a stronger than normal surface westerlies across the north Europe. Posi- 
tive NAO index brings wetter conditions in North Europe and drier to Southern Europe and in the Negative NAO index, occurs the opposite (Hurrell 1995; Wang and Schimel 2003). Nevertheless, the majority of the studies mentioned that this atmospheric pattern influences especially winter rainfall (Tildes Gomes 1998; Esteban-Parra et al. 1998; Rodrigo et al. 2000; Rodríguez-Puebla et al. 2001; Muñoz-Diaz and Rodrigo 2003; among others).

The Iberian Peninsula autumn precipitation is related with southwest circulation and is branded by a strong and unstable phenomena show up over both land and sea. Normally, this precipitation occurs between September to November and is characterized by intense rainfalls created by different physical and dynamical processes as storm track changes, low level of advection of warm, moist air or topographic configurations, can play an important role (Font 2000). These heavy precipitations have important and coercive impacts in the society, leading frequently to significant economic losses and mortality as mentioned in several studies. Hence, these events can induce important and coercive environmental hazards (Fragoso and Tildes Gomes 2008; Morata et al. 2008; Valero et al. 2009). Moreover, some studies revealed that autumn extreme rainfall is increasing in Portugal since the last half of the $20^{\text {th }}$ century (Pereira et al. 2008).

Mountain areas have important implications in rainfall behaviour, because affect the development of cloud systems and can increase the precipitation from preexisting precipitating systems, enhancing the rainfall differences between uplands and lowlands and between slopes with different exposure to moist flows (Valero et al. 2004). In addition, in these areas with steep slopes (especially with non forested land use) and small drainage basins, heavy rainfall can triggered rapid an unexpected flash flood events, landslides, debris flow, and soil erosion (Johnson and Warburton 2002; Weingartner et al. 2003; Arattano and Franzi 2004; Zêzere et al. 2005; Romero et al. 2006; González-Hidalgo et al. 2007; Surda et al. 2007; Okonski 2007; among others).

Since heavy precipitation events have important impacts in mountain areas is of major importance know with accuracy their spatial distribution in order to predict the impacts of these events and identify higher vulnerability areas. This prediction can be studied throughout testing the precision of interpolation methods and identify the less biased. Find the best method interpolate precipitation patterns in one of the biggest problems faced by meteorologists, hydrologists and climatologists. Precipitation is intermittent and spatially discontinuous variable, frequently with zero accumulations. Hence the interpolation of precipitation is more difficult than other variables (Dirks et al. 1998). Moreover in mountains environments is a special challenge because data are sparse, frequently restricted to lower elevations whereas spatial variation in precipitation can be significant (Hofierka et al. 2002). Several works have studied the validity of interpolate methods in predict rainfall, however they are focused in total, seasonal, mean, monthly or daily precipitation (Goodale et al. 1998; Dirks et al. 1998; Hofierka et al. 2002; Goovaerts 2000; Vicente-Serrano et al. 2003;
Subyani 2004; Diodato and Ceccarelli 2005; Fernández and Bravo 2007; Haiden and Pistonick 2009; among others). The extreme rainfall events are the ones that have important impacts in society and cause large economic losses, especially in mountain areas. However, there are few studies about spatial distribution of extreme rainfall events and their pattern (Kieffer Weisse and Bois 2001). In the Mediterranean environment great amounts of precipitation can occur in a short period of time, generating rapid and unexpected flash floods as reported elsewhere (Bechtold and Bazile 2001; Ferraris et al. 2002; Llasat et al. 2003; Romero et al. 2006; Barrera et al. 2006; among others). Hence, is of major importance identify the extreme rainfall patterns in mountain areas in order to predict and identify the most vulnerable areas to heavy precipitation occurrence. This has special interest in areas with lack of spatial and temporal resolution of data and in order to contribute to hazard prediction is fundamental make spatial estimations accurate as possible (Vaišis and Januševičius 2008).

The aim of this research is modelling and assess the accuracy of some well known interpolation methods in predict the extreme rainfall during the months of September, October and November (SON) calculated from monthly data between the period of 1970-2006 in a mountain area located in Portugal.

\section{Materials and Methods}

\subsection{Study area, data and statistical analysis}

The study area is situated in the interior North of Portugal (Fig. 1) and cover about $7569 \mathrm{~km}^{2}$. The geological subtract is mainly composed by granite and schist rocks from Paleozoic. The topography varies between 100 and $1991 \mathrm{~m}$ of altitude that is cut by a dense and complex fluvial network towards to Atlantic Ocean. The climate according to Köppen classification is Csb (warm temperate moist forest climate, with wet winters, dry summers, and the warmest month above $22^{\circ} \mathrm{C}$ on average). Annual mean temperature is $12.6^{\circ} \mathrm{C}$ and total annual precipitation is $2300 \mathrm{~mm}$ and is concentrated between autumn and spring.

The database used in this study was collected in the Natural Water Resources Institute (INAG) in Portugal. The INAG network collects the data from rain gauges at 9 a.m. and the series are organized according to $24 \mathrm{~h}$ time units (from 9 a.m until 9 a.m of the next day). Overall we selected a total of 29 stations with the best temporal and spatial resolution across the studied area (Fig. 1). After collect data, quality control and data homogenization were carried out according the methods described in Wijngard et al. (2003). Then in order to identify the value of SON extreme precipitation we calculate the $95^{\text {th }}$ percentile (P95) of each series from the three months. This threshold was also applied in other works (Karl and Knight 1998; Haylock and Nicholls 2000; Carvalho et al. 2004; among others).

Some descriptive statistics of P95 and altitude were performed, Mean(m), Standard Deviation (SD), Coefficient of Variation $(\mathrm{CV} \%)$, Minimum ( $\mathrm{min})$, Maximum 


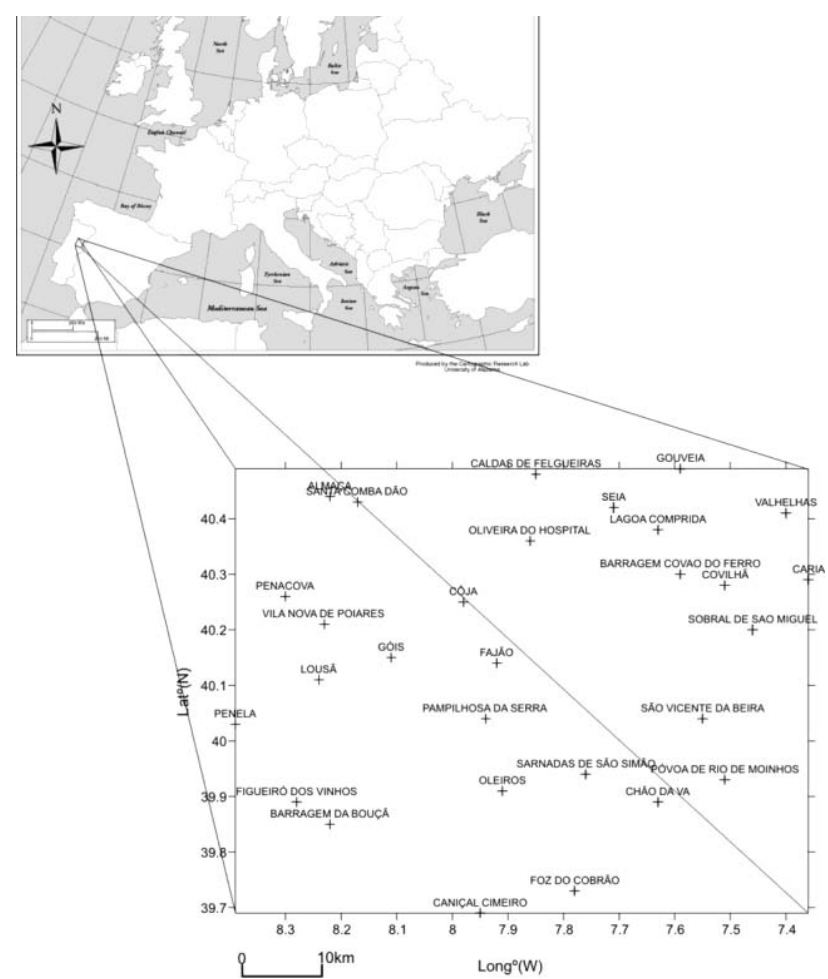

Fig. 1. Study area and stations in analysis

(max), $1^{\text {st }}$ Quartil (Q1), Median (M), $3^{\text {rd }}$ Quartil (Q3), Skewness (Sk) and Kurtosis (Kur). After identify the P95 for each station and prior to modelling data, we submit data to normal distribution test through to Shapiro wilk test (SW) (Shapiro and Wilk 1964) considered normal at a $p>0.05$. All statistical analysis were performed with STATISTICA 6.0 (Statsoft Inc).

\subsection{Interpolation methods}

Interpolation is the process of using known data values to predict unknown values (Yilmaz 2007). Currently is a topic of interest in earth sciences, geography and engineering because measurements can be time consuming, expensive and laborious in several environmental sciences (Erdogan 2009). In this study we tested some well known interpolation methods in order to predict with better accuracy the distribution of P95, namely, Inverse Distance Weighting (IDW), Local Polynomial (LP), Spline With Tension (SPT), Thin Plate Spline (TPS), Ordinary Kriging (OK) and Ordinary CoKriging (COK).

\subsubsection{Deterministic methods}

\subsubsection{Inverse Distance Weighting (IDW)}

IDW is an exact interpolator and one of the most simple and popular interpolation technique. This method assumes that every measured sample point has a local influence that reduces with the distance. To estimate an unknown value, this method will use the closest known values. Those measured points closest to the estimation point will have more influence in the predicted value (Apaydin et al. 2004; Babak and Deutsch 2009). The factor that can affect the IDW accuracy is the power fac- tor (Isaak and Srivastva 1989). In this study we compared estimates of IDW technique applying different weights, 1, 2, 3, 4 and 5. The general function of IDW (Burrough and McDonell 2009) is:

$$
\dot{Z}\left(S_{0}\right)=\sum_{i=1}^{N} \lambda_{i} Z\left(s_{i}\right),
$$

where $\dot{Z}\left(S_{0}\right)$ is the predicted value for location $\left(S_{0}\right), N$ is the number of measured points surrounding the prediction. $\lambda_{i}$ are the weights allocated to each measured point and $Z\left(s_{i}\right)$ is the observed value at the location $\left(s_{i}\right)$. The weights are a function of the inverse distance and are calculated according the formula:

$$
\lambda_{i}=\frac{d_{i 0}^{-p}}{\sum_{i=1}^{N} d_{i 0}^{-p}}
$$

The power parameter $(p)$ in this method of interpolation is the significance of the surrounding points upon the interpolated value. When the distance $(d)$ augment between measured and prediction points, the weight that the measured point has no the prediction reduce (Burrough and McDonell 2009).

\subsubsection{Local Polynomial (LP)}

LP is moderate quick deterministic and inexact interpolator. Is combination between of global polynomial methods and the moving average procedure. Using the identified data this method is fit using weighted least squares and the grid node value is set equal to this value (Yilmaz 2007; Luo et al. 2008). The LP can be of one, two or three orders. In this study we tested the first and second order defined by the formula:

Order 1

$$
F(X, Y)=a+b X+c Y
$$

Order 2

$$
F(X, Y)=a+b X+c Y+d X Y+e X^{2}+f Y .
$$

\subsubsection{Radial Basis Functions (RBF)}

Radial basis functions (RBF) are moderately quick deterministic interpolators that are exact. This method provides prediction surfaces that are comparable to the exact form of kriging and especially efficient in the absence of grid data (Buhmann 2000). RBF methods include SPT, TPS, multiquadratic, inverse multiquadratic, and completely regularized spline. They are based on the assumption that the interpolation function should pass or pass close to the data points and at the same time be as smooth as possible (Talmi and Gilat 1977). In this study we used SPT and TPS methods. In the first the tension manages the flexibility of the surface according to the character of the modelled phenomenon. The method creates a less smooth surface with values more closely constrained by the sample data amplitude. Here we considered the tension of 0.1 . In SPT, the parameter defines the weight of 
tension. Higher the weight, coarser the output surface. The spline function uses the following formula for the surface interpolation:

$$
S(x, y)=T(x, y)+\sum_{j=i}^{N} \lambda_{j} R\left(r_{j}\right),
$$

where: $J=1,2, \ldots N, N$ is the number of points, $\lambda_{j}$ are coefficients found by the solution of a system of linear equations $r_{j}$ is the distance from the point $(x, y)$ to the $\mathrm{J}^{\text {th }}$ point. $T(x, y)$ and $R(r)$ are defined differently, depending on the selected option. In the case of SPT:

$$
T(x, y)=a 1
$$

and

$$
R(r)=-\frac{1}{2 \pi \phi^{2}}\left[\ln \left(\frac{r \phi}{2}\right)+c+K_{0}(r \phi)\right],
$$

where $\phi^{2}$ is the parameter entered at the command line, $r$, the distance between the point and the sample. $K_{0}$ is the modified Bessel function and $\mathrm{c}$ is a constant equal to 0.57721 (Franke 1982). Details about Bessel function are mentioned in Smith et al. (2009). TPS is a method that ensures a smooth surface, together with continuous first derivate surfaces. It works by fitting a surface a surface at each sample point, so the surface can be can be smother than if data were fitted exactly (Tait et al. 2006). The definition of this method is given by a linear combination (Luo et al. 2008) and is calculated according the formula:

$$
z_{p}=w_{i} \phi\left(r_{i}\right),
$$

where $z_{p}$ is the estimated value for the surface at grid point $p, \phi\left(r_{i}\right)$ is the RBF selected, with $\left(r_{i}\right)$ being the radial distance from point $p$ to the $1^{\text {st }}$ data point. The weight $w_{i}$ is estimated from the data points (Smith et al. 2009). In the present case I selected TPS $(\phi)$ as RBF, hence:

$$
\phi=c^{2} r^{2} \ln (c r),
$$

where $c$ is the smoothing factor and $\mathrm{r}$ is the vector (Smith et al. 2009). In the present study I considered a smoothing factor of 0.5 .

\subsubsection{Geostatistical Methods}

Geostatistical techniques are extensively described in literature (Isaak and Srivastva 1989; Goovaerts 1999; Webster and Oliver 2007; among others). This method is a moderately quick interpolator that takes into account both the distance and the degree of variation between known data points (Chaplot et al. 2006; Kumar et al. 2007; Luo et al. 2008). One of the many advantages of kriging is the estimation of a spatial correlation between the measured points given by the:

$$
\gamma(h)=\frac{1}{2 N(h)} \sum_{i=1}^{N(h)}\left[Z\left(s_{i}\right)-Z\left(s_{i}\right)+h\right]^{2},
$$

where $\mathrm{N}(h)$ is the number of data pairs within a given class of distance and direction. The semi-variance can be a function of distance and direction, and so can identify the variable spatial dependence in a certain direction (anisotropy) (Luo et al. 2008). Normally to describe a reliable estimation of a semi-variogram are needed at least 150 data, and larger are needed to observe some anisotropy (Webster and Oliver 2007). Hence in this study the computed variograms are omni-directional (assuming that the variability is identical in all directions) due the lack of data. Others studies have also calculated semi-variograms with similar amounts of datasets (Goovaerts 2000; Diodato and Ceccarelli 2005; Jalali 2007; Vaikasas 2010). There is several types of kriging, OK, simple kriging and universal kriging. In this study we selected the OK because the direction trend of the variable was unknown. Kumar et al. (2007) pointed out that in this situation $\mathrm{OK}$ is the best kriging method. $\mathrm{OK}$ is a univariate method and one of the most widespread procedure in GIS packages. As other kriging methods, use point or block computations, resulting in smoothed surface and inexact interpolation. Assumes a constant but unknown average and estimates the average value as a constant on searching of neighbourhood (Goovaerts 1999; Kumar et al. 2007; Smith et al. 2009). OK is calculated according the formula:

$$
Z^{*}(u)=\sum_{i=1}^{n(h)} \lambda_{i}(u) Z\left(u_{i}\right)+\left[1-\sum_{i=}^{n(h)} \lambda_{i}(u)\right] m,
$$

where $Z^{*}(u)$ is the OK estimate at a spatial location $u$, $n(h)$ is the number of data applied at the known locations given a neighbourhood. $Z\left(u_{i}\right)$ are the $n$ measured points $\left(u_{i}\right)$, situated close to $u$ calculated from the spatial covariance matrix based on the spatial continuity (Kumar et al. 2007).

Since rainfall can be strongly influenced by the elevation we used other type of kriging that can use information from several variable types. In order to make a relation between precipitation and altitude we applied the COK. This method is based in the relation of two or more variables to help to make the prediction more accurate and is especially useful when both variables are related. The main variable of interest $\left(Z_{1}\right)$ and both autocorrelation for $Z_{1}$ and cross correlations between $Z_{1}, Z_{2} \ldots$ are used to make better predictions. In this study we classified as main variable the P95 and altitude as second variable. The formula of COK is given by:

$$
Z_{O C K}=\left(S_{0}\right)=\sum_{i=1}^{n(u)} \lambda_{i} z_{1}\left(s_{i}\right)+\sum_{i=1}^{n\left(u^{\prime}\right)} \lambda_{j} z_{2}\left(s_{j}\right),
$$

where $z_{1}$ is the data of the main variable, in this case the precipitation selected in the $\left(S_{0}\right)$ neighborhood observation $\left(s_{i}\right), z_{2}$ is the data of the second variable (altitude) selected in the $\left(S_{0}\right)$ neighborhood observations $\left(s_{j}\right), \lambda_{i}$ and $\lambda_{j}$ are the weights associated with the distance (Diodato and Ceccarelli 2005). 


\subsubsection{Assessment criteria for interpolation techniques}

The assessment criterion is based on the errors produced by each model (Observed - Predicted). They provide important information, especially when using and comparing different methods (Smith et al. 2009). There are several validation methods. Here we used the cross validation procedure that compares measured precipitation values with the predicted ones. Cross validation is achieved by taking each observation in turn out of the sample and estimating from the remaining values. This method is an excellent alternative to solving the inconvenience of redundant data collection (Webster and Oliver 2007). The produced errors in each interpolation technique allowed us to calculate mean error (ME) and root mean square error (RMSE), indices used extensively in the literature to evaluate the accuracy of the interpolation methods (McGrath et al. 2004; Hooker and Nathanail 2006; Luo et al. 2008; Bourennane et al. 2006; Pereira and Úbeda 2010). ME and RMSE are calculated according the formulas:

$$
\begin{gathered}
M E=\frac{1}{N} \sum_{i=1}^{n}\left\{z\left(x_{i}\right)-\hat{z}\left(x_{i}\right)\right\}, \\
R M S E=\sqrt{\frac{1}{N}} \sum_{i=1}^{N}\left\{z\left(x_{i}\right)-\hat{z}\left(x_{i}\right)\right\}^{2},
\end{gathered}
$$

where $z\left(x_{i}\right)$ is the observed value, $\hat{z}\left(x_{i}\right)$ the predicted value and $\mathrm{N}$ the number of samples. Ideally ME should be 0 if the interpolation is unbiased. The RMSE was used to compare the performance of the different methods by seeing how close predicted values match the measured values. The method with smaller RMSE is the best predictor (Robinson and Metternicht 2006; Luo et al. 2008). The RMSE is an indicator of the sensitivity to outliers, identify the magnitude of extreme errors and it is low when there is a central tendency and extreme errors are small (Ashraf et al. 1997; Nalder and Wein 1998). The Relative improvement (RI\%) of the best method compared with the others is calculated according the formula:

$$
R I(\%)=\frac{\left(R M S E_{\text {Best }}-R M S E_{\text {Current }}\right)}{R M S E_{\text {Best }}} \times 100,
$$

where $R M S E_{\text {Best }}$ is the minimum value of RMSE and $R M S E_{\text {Current }}$ is the current model.

In addition, to observe the difference between means of observed and predicted values we applied paired $t$-tests for dependent samples, significant at a $p<0.05$. All interpolation tests were performed in SURFER 8.0 (Golden software) and ArcGis 9.3 (ESRI software) for windows.

\section{Results and Discussion}

\subsection{Descriptive parameters}

Table 1 summarizes basic statistics of the two variables in study. The mean altitude of sample points is $476.13 \mathrm{~m}$ and P95 is $264.06 \mathrm{~mm}$ during SON and presents a higher $\mathrm{CV} \%$, especially in altitude due great differences between observation points.
The places with higher elevation are located in the Northeast corner of the studied area and the lower in Northwest part (Fig. 2a). Fig. 2b shows the symbol map of P95. Clear spatial patterns can be identified, showing higher values of P95 in some points located at Northeast. In opposition, lower values were identified in the Northwest part of the studied area. The higher P95 values were located at the higher altitude points.

Table 1. Descriptive statistics for P95 and altitude respective Ln transformations

\begin{tabular}{ccccc}
\hline & $\begin{array}{c}\text { P95 } \\
(\mathrm{mm})\end{array}$ & $\begin{array}{c}(\text { Ln) } \\
\text { P95 }\end{array}$ & $\begin{array}{c}\text { Altitude } \\
(\mathrm{m})\end{array}$ & $\begin{array}{c}(\mathrm{Ln}) \\
\text { Altitude }\end{array}$ \\
\hline $\mathrm{m}$ & 264.06 & 5.50 & 476.13 & 5.95 \\
$\mathrm{SD}$ & 109.55 & 0.37 & 353.04 & 0.64 \\
$\mathrm{CV}(\%)$ & 41.77 & 6.72 & 74.14 & 10.75 \\
$\mathrm{~min}$ & 123.4 & 4.81 & 116 & 4.75 \\
Q1 & 196 & 5.27 & 253 & 5.53 \\
M & 238.7 & 5.47 & 426 & 6.05 \\
Q3 & 306.5 & 5.72 & 572 & 6.34 \\
max & 608.48 & 6.41 & 1560 & 7.35 \\
Sk & 1.593 & 0.28 & 1.989 & 0.26 \\
Kur & 3.432 & 0.47 & 4.33 & -0.08 \\
\hline
\end{tabular}

This positive and significant relationship can be observed in the Fig. 2b. Several studies also founded positive relations between precipitation and altitude (Daly et al. 1994; Hutchinson 1998; Hay et al. 1998; Diodato and Ceccarelli 2005; Fernández and Bravo 2007). The histograms of altitude and P95 are strongly skewed, the Kur is very sharp caused by the fact that the majority of points are located in lower elevation. Both distributions did not respect the normality test (Fig. 2d and f). This data distribution is due the existence of extreme values. The presence of outliers lead to biased conclusions in statistical and geostatistical analysis. In order to avoid these problems I transformed P95 data Log-normally (Ln) and tested again their normality. Ln transformation resulted in smaller Sk and Kur in both variables (Table 1, Fig. 2e and g). With this transformation, data followed the Gaussian distribution and was used to modelling spatial distribution of $\mathrm{Ln}(\mathrm{P} 95)$ and $(\mathrm{Ln})$ Altitude in COK.

\subsection{Spatial structure}

The semi-variogram gives the spatial structure of the variable and the statistical correlation of the closest points. As distance increases the probability of the samples being correlated is smaller.

The omni-directional semi-variograms for (Ln)P95 and $(\mathrm{Ln})$ Altitude are showed in the Fig. 3a and b. Semivariance increases with the distance, confirming that two observed (Ln)P95 close to each other are more similar and their square difference is smaller. Among all tested theoretical models, the semi-variograms has been fitted with the wave (hole effect). This model is reflects the existence of cyclic phenomena (Jones and Ma 2000; Goovaerts 2000). This fact was already expected, because of the topographic variability and their influence on P95, even in small scale. However, here, this behaviour is consequence of the existence of two major elevation 

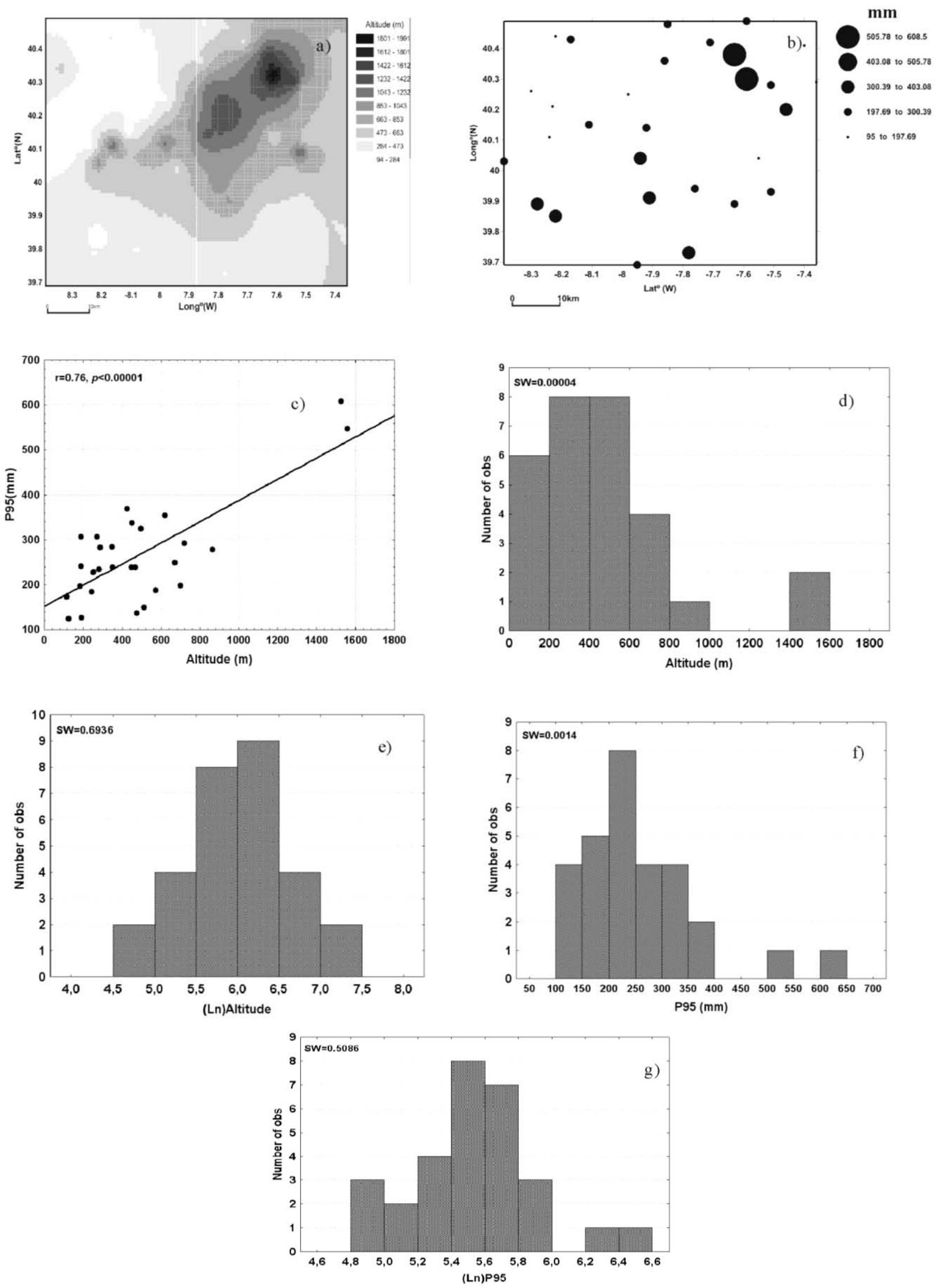

Fig. 2. Digital elevation model of the studied area (a), Symbol map of P95 in the studied area (b), Scaterplot between Altitude and P95 (c), Histogram for altitude (d), Histogram for (Ln)Altitude (e), Histogram for P95 (f) and Histogram for Ln(P95) (g). SW (Shapiro wilk test). Normal distribution considered at a $p>0.05$ 

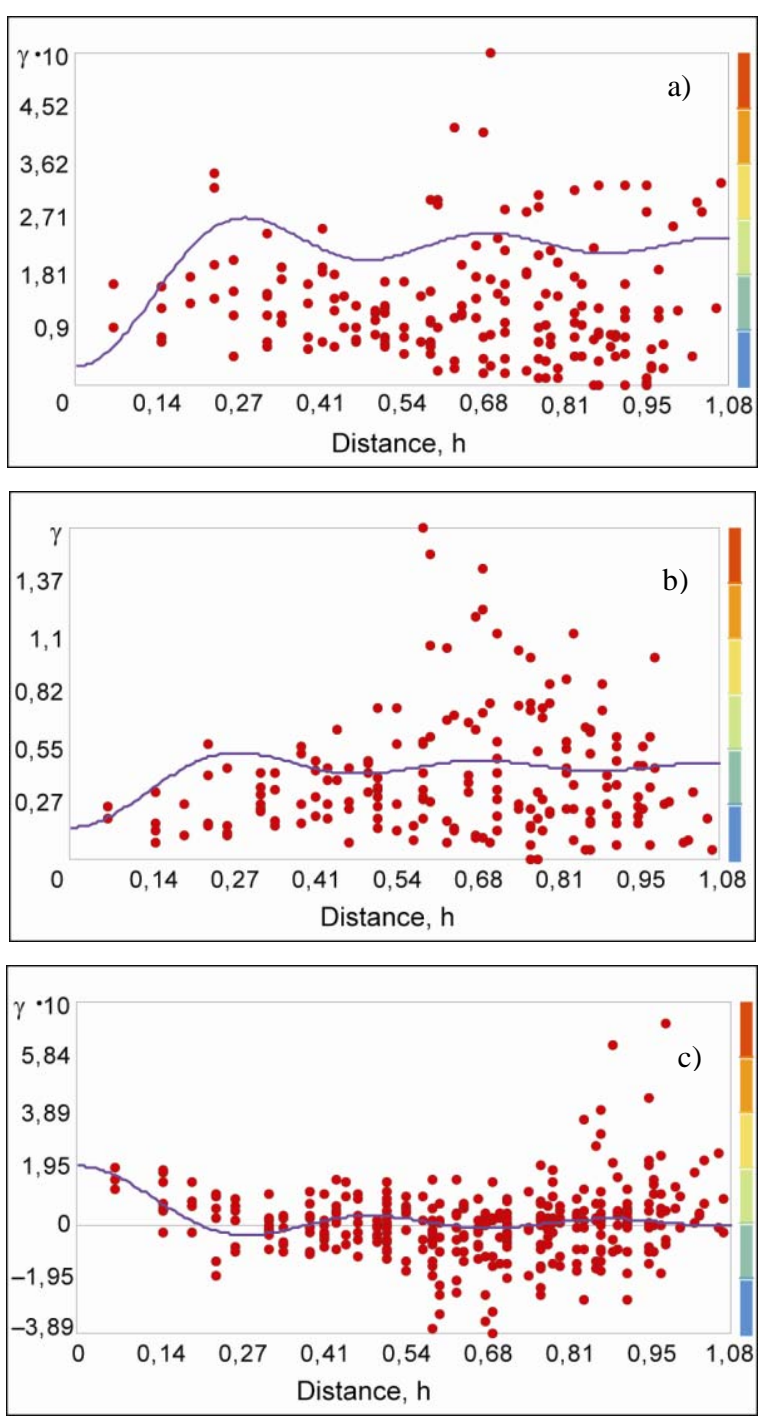

Fig. 3. Omni-directional semi-variograms: a) (Ln)P95; b) (Ln)Altitude, with their cross-covariance model; c) Blue line fits the theoretic model. Distance in degrees $\left(1^{\circ}=87.2 \mathrm{~km}\right)$

points that induce an important increase of (Ln)P95 (see Fig. 2a). Two main areas with higher (Ln)P95 can be identified in the semi-variogram exposed in the Fig. 3a. The first is located between $0.14^{\circ}$ and $0.27^{\circ}(12.19 \mathrm{~km}$ and $23.57 \mathrm{~km}$, respectively) and the second between $0.54^{\circ}$ and $0.70^{\circ}(47.05 \mathrm{~km}$ and $60.99 \mathrm{~km})$. The Fig. $3 \mathrm{~b}$ shows the semi-variogram of the (Ln)Altitude and can be observed a very similar shape to (Ln)P95 semi-variogram, despite of the first area is not so evident. The cross-covariance cloud gives us the spatial covariation between ( Ln)P95 and (Ln)Altitude (Fig. 3c) and is defined as half the expectation of the product of the increment of two variables. Measures the how a value of an attribute $x_{i}$ at one location is related to the value of another attribute $z_{i}$ a vector $\mathrm{h}$ further apart. Normally, as the distance increases the relation between the two different points weakens. The nugget effect in both variables is small, 0.0300 for (Ln)P95 and 0.157 for (Ln)Altitude, respectively. This means that sampling density is adequate to reveal the spatial structures (Table 2). The spatial correlation of the both variables is quite similar. The first goes until $27.03 \mathrm{~km}$ and the second until $31.39 \mathrm{~km}$. The Nug/Sill ratio can be regarded as a criterion to classify spatial dependence of variables. If the ratio is smaller than $25 \%$, the variable presents a strong spatial dependence, between $25 \%$ and $75 \%$, the variable shows a moderate spatial dependence and higher than $75 \%$ has a weak spatial dependence (Liu et al. 2004). In this work, Nug/Sill ratios were $11 \%$ and $28 \%$ for (Ln)P95 and (Ln)Altitude respectively. This suggest that (Ln)P95 has a strong spatial dependence and (Ln)Altitude moderate. Normally, lower spatial dependences are related with intrinsic factors (topography and geomorphology) and weak spatial dependences to extrinsic factors (human factors) (Lu et al. 2007). Hence, in this study the lower Nug/Sill ratio, especially of ( $\mathrm{Ln}) \mathrm{P} 95$, shown that spatial variability is related with natural factors. This higher spatial dependency of (Ln)P95 is due the great influence of topography in precipitation patterns.

Table 2. Parameters for onmidirectional semi-variograms

\begin{tabular}{lcccc}
\hline Variable & $\begin{array}{c}\text { Nugget } \\
\text { effect }\end{array}$ & Sill & Range & $\begin{array}{c}\text { Nug/Sill } \\
\text { ratio }\end{array}$ \\
\hline (Ln)P95 & 0.300 & 2.72 & $0.31^{\circ}(27.03 \mathrm{~km})$ & 0.11 \\
(Ln)Altitude & 0.157 & 0.55 & $0.36^{\circ}(31.39 \mathrm{~km})$ & 0.28 \\
\hline
\end{tabular}

\subsection{Interpolation methods accuracy}

The ME and RMSE calculated from the residuals obtained from each model are presented in the Table 3. Considering all the methods, the $\mathrm{ME}$ in general was closed to 0 and ranged between -0.048 and 0.040 , and suggested that in all distributions the predictions were unbiased. The RMSE varied between 0.2955 and 0.3848 . On average, with exception of LP1 and LP2, all models sub-estimate original values (observed $>$ predicted).

Table 3. Summary statistics of the interpolation methods accuracy. In bold the less biased method

\begin{tabular}{llcccc}
\hline Method & Min & Max & ME & RMSE & RI(\%) \\
\hline IDW 1 & -0.790 & 0.746 & 0.02212 & 0.3587 & 21.38 \\
IDW 2 & -0.657 & 0.683 & 0.03576 & 0.3379 & 14.34 \\
IDW 3 & -0.565 & 0.624 & 0.04085 & 0.3318 & 12.28 \\
IDW 4 & -0.520 & 0.603 & 0.04084 & 0.3355 & 13.53 \\
IDW 5 & -0.515 & 0.676 & 0.03935 & 0.3435 & 16.24 \\
LP 1 & -0.569 & 0.455 & -0.04864 & 0.3144 & 0.39 \\
LP 2 & -0.512 & 0.781 & -0.008169 & 0.3746 & 0.516901 \\
SPT & $-\mathbf{0 . 5 0 7}$ & $\mathbf{0 . 5 3 3}$ & $\mathbf{0 . 0 2 0 2 9}$ & $\mathbf{0 . 2 9 5 5}$ & 0.414257 \\
TPS & -0.649 & 0.795 & 0.003259 & 0.3511 & 0.908943 \\
OK & -0.912 & 0.690 & 0.01101 & 0.3848 & 18.81 \\
OCK & -0.659 & 0.634 & 0.004846 & 0.3347 & 30.22 \\
\hline
\end{tabular}



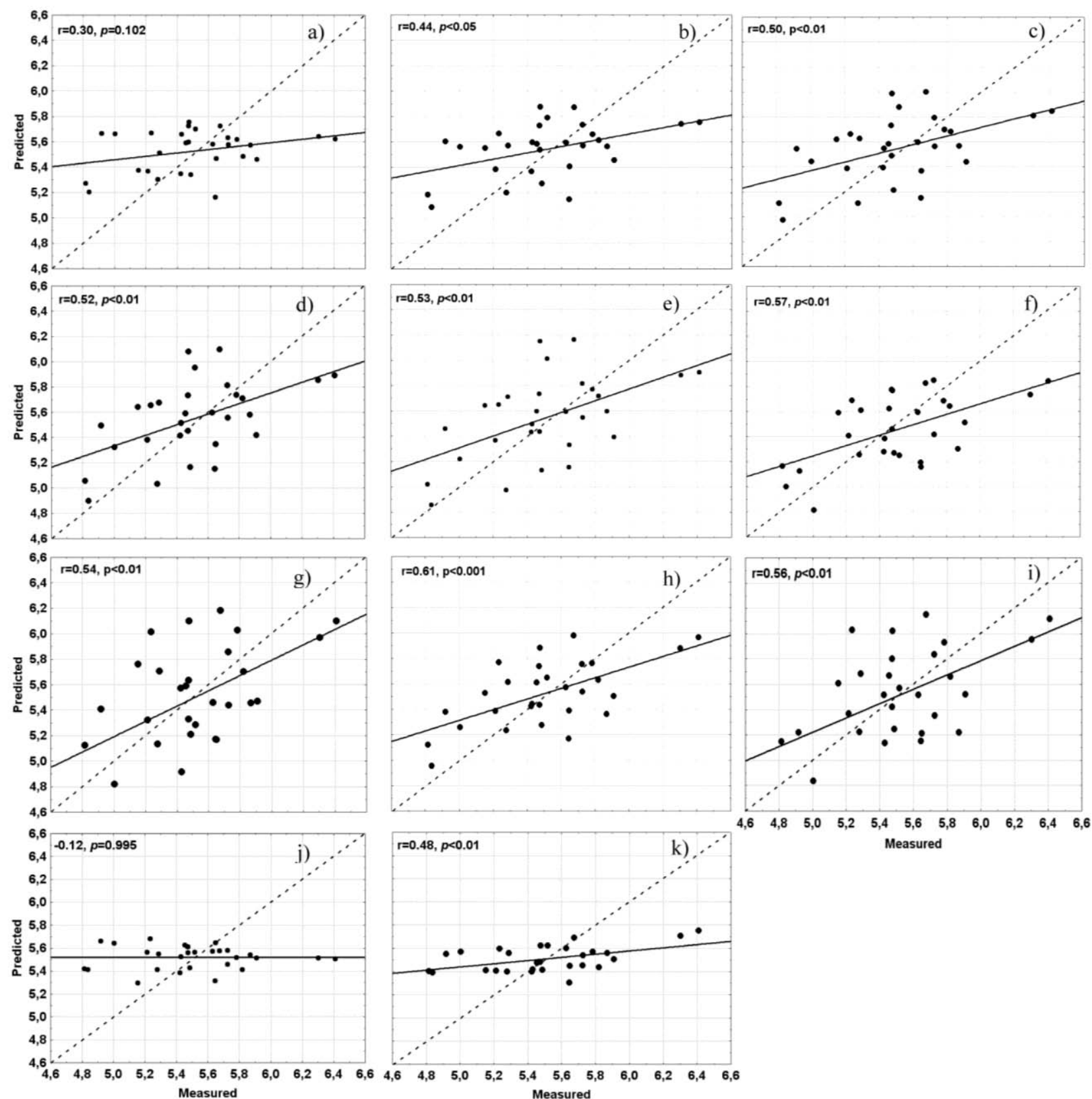

Fig. 4. Scaterplots of the observed against estimated values in the studied interpolation methods. a) IDW1, b) IDW2, c) IDW3, d) IDW4, e) IDW5, f) LP1, g) LP2, h) SPT, i) TPS, j) OK, k) COK. Bold line (best linear fit), and dotted line (1:1)

From all tested models the most accurate to interpolate (Ln)P95 was the SPT with the lower RMSE. These results agree with other studies that also identified this method as a good interpolator of precipitation distribution (Hofierka et al. 2002; Stuart and Jarvis 2004). IDW was estimated with the powers of one two, tree, four and five and they presented different results.

From all the best predictor was IDW3. In relation to LP methods, the most precise was LP1. OK was the most biased of all methods with an error of $30.22 \%$. Beside the error reduction with the incorporation of secondary information with $\mathrm{COK}$, the prediction was still more biased than SPT. In any case the mean of observed values were different from estimated values, however, in RBF, kriging and LP2 methods they are more similar than in the others (Table 3 ).

The correlations between observed and estimated values by each model are exposed in the Fig. 4 . The coefficient of correlation was in the range of -0.12 and 0.61 . The higher correlation was identified in SPT method and the lower in OK, precisely the best and worst interpolators of (Ln)P95 in the selected area. The residuals produced in each model are exposed in the Fig. 5. All distributions respected the gaussian distribution and hence the majority of the errors are close to 0 . However in the case of LP2 model (Fig. 4g), beside the SW test result showed a $p>0.05$, it is clear that the high percentage of the errors are not concentric to 0 value. This dispersion can be also observed in the scaterplot of the Fig. $4 \mathrm{~g}$. 
The interpolated map with the best predictor (SPT) is shown in the Fig. 6. The areas where (Ln)P95 in SON is higher are located at Northeast and Southwest and as expected are in higher mountain areas. In opposition, the areas with lower (Ln)P95 in SON are situated in Northwest and in the Northeast corner of the analysed area. After the interpolation it is clearly observable a trend from Southwest to Northeast area related with altitude increase. In the Northwest area the lower occurrence of higher values is due lower topography.

In the Northeast corner the reduced values of (Ln)P95 can be justified by the "shelter effect" or "rain shadow effect" of mountain as observed in other studies
(Kieffer Weisse and Bois 2001; Diodato and Ceccarelli 2005; Gilles et al. 2006; Minder et al. 2008; among others). In mountain environments the amount of precipitation can vary from a place to another significantly even in small distances. There are two effects on precipitation caused by mountains. The first, the orographic effect (already mentioned above) occurs on the windward side of the mountain. The amount of precipitation increases importantly with the altitude on the windward side of the mountain. The second is the "shelter effect" or "rain shadow effect" that happens no the leeward side of the mountain.
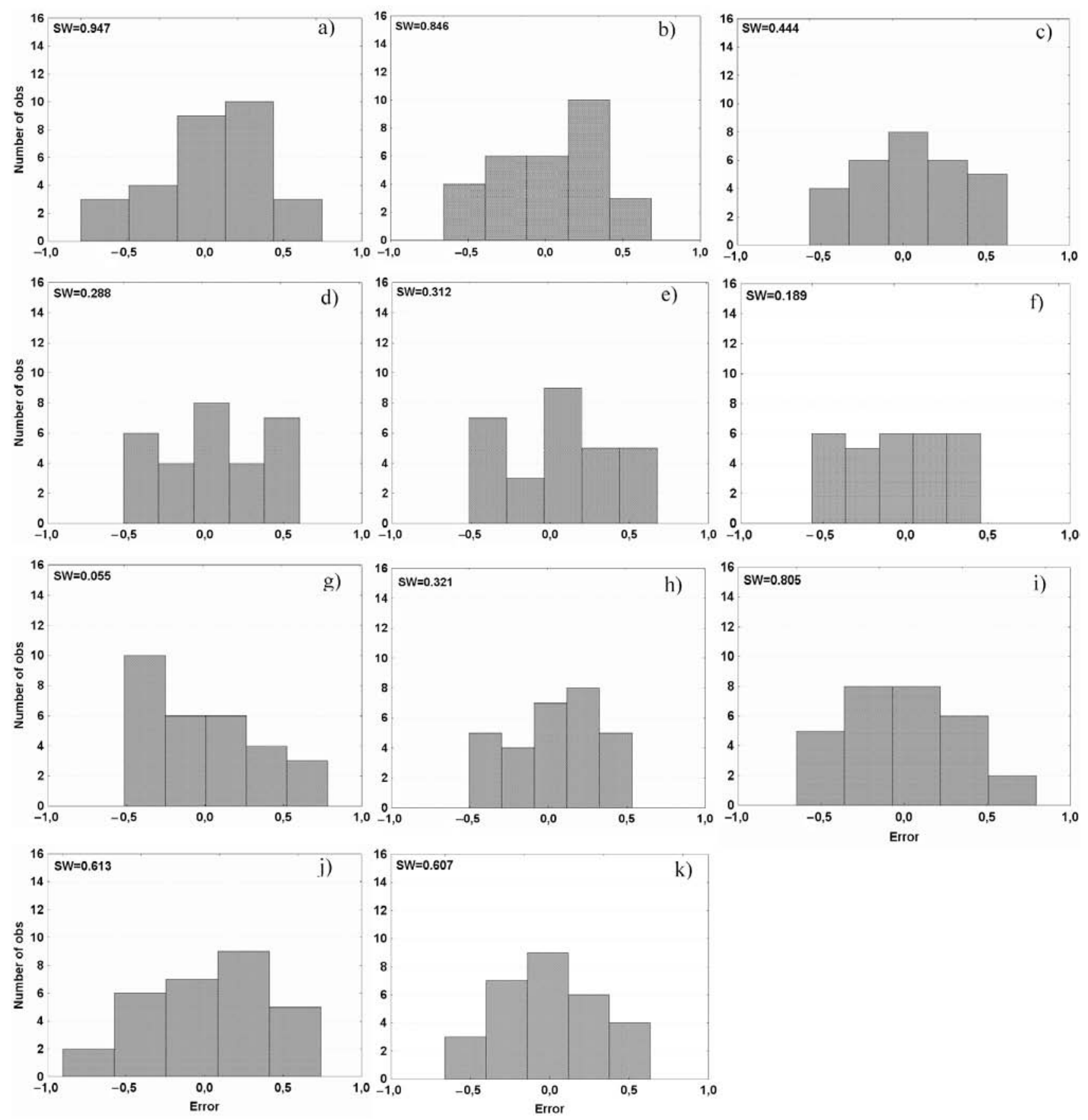

Fig. 5. Histogram of the errors resilting from: a) IDW1; b) IDW2; c) IDW3; d) IDW4; e) IDW5; f) LP1; g) LP2; h) SPT; i) TPS; j) $\mathrm{OK} ; \mathrm{k}) \mathrm{COK}$. SW(Shapiro-wilk test). Normal distribution considered at a $p$ 


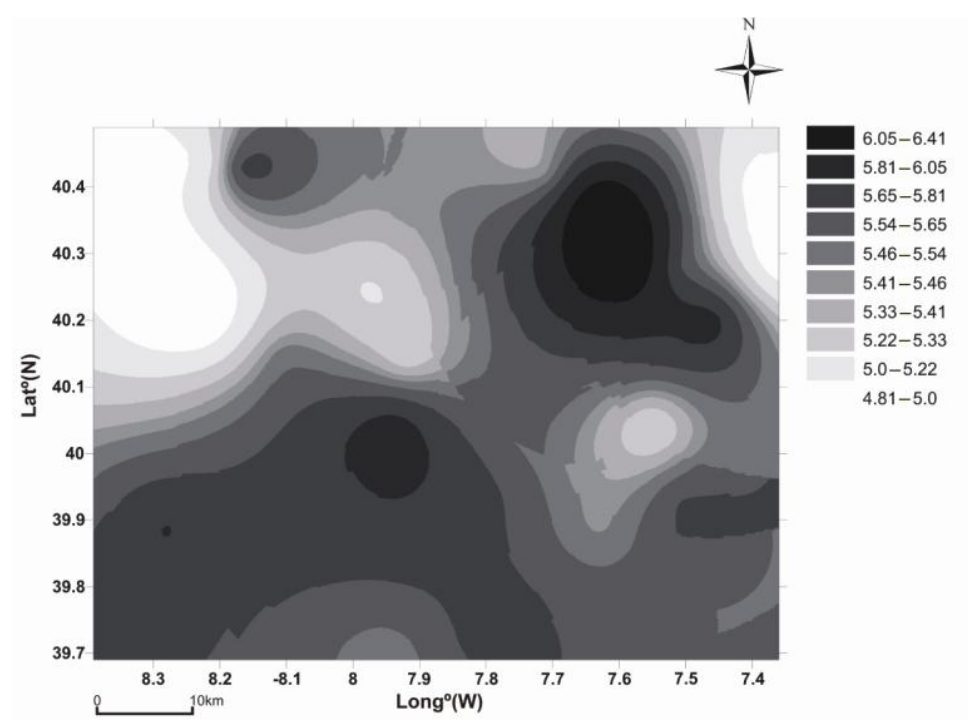

Fig. 6. Spatial distribution of (Ln)P95 according to SPT interpolation method

In this side the precipitation is reduced significantly because the major quantity of rainfall occurred in the windward side of the mountain and the air masses arrive dry to the leeward side of the mountain. This foehn effect causes a very high variability in precipitation patterns in mountain areas.

In Portugal, SON precipitation is related with southwest fluxes and after moist masses pass all mountain range is normal that they arrive to the leeward side of the mountain (in this case located at Northeast) dry. This mechanism can explain the rapid reduction of (Ln)P95. The map produced with the less biased method suggested that precipitation patterns are related with small scale variability imposed by orography in local circulations.

The knowledge of the extreme precipitation spatial pattern in mountainous areas is of major importance in order to contribute to a sustainable and correct land use planning. These events are related with flashfloods, especially coercive in mountainous areas with steep slopes, triggering soil erosion and landsides that produce important economic losses. It is important to refer that study area during summer time is frequently affected by wildfires that reduce vegetation cover and expose soil to rainfall erosion. Since these major precipitation events occur immediately after fire season (June-August), the unprotected soil is vulnerable to erosion and the loss of nutrients can be higher.

\section{Conclusions}

Estimation with precision precipitation patterns in mountain areas is complex due the lack of available observation points and the small scale variation induced by orography. However, is of major importance predicted with accuracy, precipitation distribution, especially extreme precipitation that is responsible for flash floods, landslides and soil erosion. In Portugal, these events occurred especially in autumn months, therefore, is of main interest know the spatial variability in this period in higher hazard areas and hence anticipate the potential occur- rence of environmental problems produced by extreme precipitation.

Due special importance of extreme precipitation in mountainous areas is fundamental to predict with less error as possible. Based on this study some important conclusions are observed:

1. P95 is strongly dependent of orography and great differences are identified between stations located at higher and lower altitudes.

2. The relation between altitude and precipitation is observed in the omni-directional variograms produced where it is evident the effects of mountains located at $12.19 \mathrm{~km}$ and $23.57 \mathrm{~km}$, especially the second one, on extreme precipitation increase. The lower Nug/Sill ratio and consequent spatial dependency shows that variability of P95 is mainly due topographical variations

3. From the 11 models tested in this work, the less biased was SPT and OK the less accurate. Even with the introduction of altitude as secondary information in $\mathrm{COK}$ technique, the error was still higher than SPT. This means that kriging methods are not always the better interpolation techniques as defended in several publications. The precision of the algorithms is also evaluated in the relation between the observed and predicted values. The higher correlation is observed in SPT and the lower in OK which confirms that the first method estimates with better accuracy in relation to all others.

4. The areas with higher P95 precipitation are observed in Southwest and Northeast, revealing also a increase trend between these areas. The lower P95 values are registered in Northwest corner due lower altitude and in the Northeast corner as consequence of rain shadow effect.

5. The results obtained from this study are a valuable contribution to land use planning and prediction of areas with more incidence of extreme precipitation during SON. With accurate information about spatial distribution of extreme precipitation, environmental problems caused by flash floods, landslides or soil erosion can be avoided. Although special attention should be paid to the higher 
amounts of P95 occurred in higher altitude areas that can induce important flash floods in lowland areas, especially in places located near torrents or fluvial courses. The information obtained in this study is important to develop a sustainable landscape planning and environmental management.

\section{References}

Apaydin, H.; Sonmez, F. K; Yildirim, Y. E. 2004. Spatial interpolation techniques for climate data in GAP region in Turkey, Climate Research 28(1): 31-40. doi:10.3354/cr028031

Arattano, M.; Franzi, L. 2004. Analysis of different watersediment flow processes in mountain torrent, Natural Hazards and Earth System Sciences 4: 783-791. doi:10.5194/nhess-4-783-2004

Ashraf, M.; Loftis, J. C.; Hubbard, K. G. 1997. Application of geostatistics to evaluate partial weather station networks, Agric. Forest Meteorol. 84(3-4): 255-271. doi:10.1016/S0168-1923(96)02358-1

Babak, O.; Deutsch, C. 2009. Statistical approach to inverse distance interpolation, Stoch Environ Res Risk Assess 23(5): 543-553. doi:10.1007/s00477-008-0226-6

Barrera, A.; Llasat, M. C.; Barriendos, M. 2006. Estimation of extreme flash flood evolution in Barcelona county from 1351 to 2005, Natural Hazards and Earth System ScienF 0 es 6(4): 505-518. doi:10.5194/nhess-6-505-2006

Bechtold, P.; Bazile, E. 2001. The 12-13 November 1999 flash flood in southern of France, Atmospheric Research 56(1): 171-189. doi:10.1016/S0169-8095(00)00097-1

Bourennane, H.; Dère, Ch.; Lamy, I.; Cornu, S.; Baize, D.; van Oort, F.; King, D. 2006. Enhancing spatial estimates of metal pollutants in raw wastewater irrigated fields using topsoil organic carbon map predicted from aerial photography, Science of the Total Environment 361(1-3): 229 248. doi:10.1016/j.scitotenv.2005.05.011

Brunetti, M.; Colacino, M.; Maugeri, M.; Nanni, T. 2001. Trends in daily intensity of precipitation in Italy from 1951 to 1996, International Journal of Climatology 21(3): 299-316. doi:10.1002/joc.613

Buhmann, M. D. 2000. Radial basis functions, Acta Numerica 9: $1-38$

Burrough, P. A.; McDonell, R. A. 2009. Principles of GeR graphical Information Systems. Oxford university press, New York. 356 p.

Carvalho, L. M. V.; Jones, C.; Liebmann, B. 2004. The South Atlantic convergence zone: Intensity, form, persistence, and relationships with interseasonal to interannual activity and extreme rainfall, Journal of Climate 17(1): 88-108. doi:10.1175/1520-0442(2004)017

Chaplot, V.; Darboux, F.; Bourennane, H.; Leguédois, S.; Silvera, N.; Phachomphon, K. 2006. Accuracy of interpolation techniques for derivation of digital elevation models in relation to landform types and data density, Geomorphology 77(1-2): 126-141. doi:10.1016/j.geomorph.2005.12.010

Daly, C.; Neilson, R. P.; Philips, D. L. 1994. A statistical topographic model for mapping climatological precipitation over mountainous terrain, Journal of Applied Meteorology 33(2): 140-158. doi:10.1175/1520-0450(1994)033

Diodato, N.; Ceccarelli, M. 2005. Interpolation processes using multivariate geostatistics for mapping of climatological precipitation mean in the Sannio Mountains (Southern Ita- 1y), Earth Surface Processes and Landforms 30(3): 259268. doi:10.1002/esp.1126

Dirks, K. N.; Hay, J. E.; Stow, C. D.; Harris, D. 1998. High resolution rainfall on Norfolk Island Part II. Interpolation of rainfall data, Journal of Hydrology 208(3-4): 187-193. doi:10.1016/S0022-1694(98)00155-3

Dünkeloh, A.; Jacobeit, J. 2003. Circulation dynamics of Mediterranean precipitation variability, International Journal of Climatology 23(15): 1843-1866. doi:10.1002/joc.973

Erdogan, S. 2009. A comparison of interpolation methods for producing digital elevation models at a field scale, Earth Surface and Landforms 34(3): 366-376. doi:10.1002/esp.1731

Esteban-Parra, M. J.; Rodrigo, F. S.; Castro-Daz, Y. 1998. Spatial and temporal patterns of precipitation in Spain for the period 1880-1992, International Journal of ClimatoO ogy 18(14): 1557-1574. doi:10.1002/(SICI)1097-0088

Fernández, C. J.; Bravo, J. I. 2007. Evaluation of diverse geometric and geostatistical estimation methods applied to annual precipitation in Asturias (NW Spain), Natural $R H$ Q sources Research 16(3): 209-218. doi:10.1007/s11053-007-9053-6

Ferraris, L.; Rudari, R.; Siccardi, F. 2002. The uncertainty in the prediction of flash floods in the northern Mediterranean environment, Journal of Hidrometeorology 3(5): 714727.

Font, I. 2000. Climatología de España y Portugal. 2nd edn. Ediciones. Universidad de Salamanca Spain. $422 \mathrm{p}$.

Fragoso, M.; Tildes Gomes, P. 2008. Classification of daily abundant rainfall patterns and associated large-scale atmospheric circulation types on southern of Portugal, $I Q \square$ ternational Journal of Climatology 28(4): 537-544. doiI:10.1002/joc. 1564

Franke, R. 1982. Smooth Interpolation of Scattered Data by Local Thin Plate Splines, Comp. \& Maths. with Appls 8(4): 237-281. doi:10.1016/0898-1221(82)90009-8

Gilles, D.; Christian, W.; Nicole, M.; Lucien, H.; Laurent, P. 2006. Topography and recent winter rainfall regime change in temperate western European areas: A case study in the Rhine-Meuse basin, International Journal of ClimD $\square$ tology 26(6): 785-796. doi:10.1002/joc. 1285

González-Hidalgo, J. C.; Peña-Monne, J. L.; De Luis, M. 2007. A review of daily soil erosion in western Mediterranean areas, Catena 71(2): 193-199. doi:10.1016/j.catena.2007.03.005

Goodale, C. L.; Aber, J. D.; Ollinger, S. V. 1998. Mapping monthly precipitation, temperature, and solar radiation for Ireland with polynomial regression and digital elevation model, Climate Research 10(1): 35-49. doi:10.3354/cr010035

Goovaerts, P. 1998. Geostatistical tools for characterizing the spatial variability of microbiological and physicochemical soil properties, Biol Fertil Soils 27(4): 315-334.

Goovaerts, P. 1999. Geostatistics in soil science: state of art and perspectives, Geoderma $89(1-2)$ : 1-45. doi:10.1016/S0016-7061(98)00078-0

Goovaerts, P. 2000. Geostatistical approaches for incorporating elevation into spatial interpolation of rainfall, Journal of Hydrology 228(1-2): 113-129. doi:10.1016/S0022-1694(00)00144-X

Haiden, T.; Pistotnik, G. 2009. Intensity-dependent parameterization of elevation effects in precipitation analysis, Advances in Geosciences 20: 33-38. doi:10.5194/adgeo-20-33-2009 
Hay, L.; Viger, R.; McCabe, G. 1998. Precipitation interpolation in mountainous regions using multiple linear regression, Hydrology, Water Resources and Ecology in Headwaters IAHS 248: 33-38.

Haylock, M.; Nicholls, N. 2000. Trends in extreme rainfall indices for an updated high quality dataset for Australia, 1910-1998, International Journal of Climatology 20(13): 1533-1541. doi:10.1002/1097-0088

Hofierka, J.; Parajka, J.; Mitasova, H.; Mitas, L. 2002. Multivariate interpolation of precipitation using regularized spline with tension, Transactions in GIS 6(2): 135-150. doi:10.1111/1467-9671.00101

Hooker, P. J.; Nathanail, C. P. 2006. Risk-based characterization of lead in urban soils, Chemical Geology 226(3-4): 340-351. doi:10.1016/j.chemgeo.2005.09.028

Hurrell, J. W. 1995. Decadal trends in the North Atlantic oscillation and relationship to regional temperatures and precipitation, Science 269: 676-679.

Hutchinson, M. F. 1998. Interpolation of rainfall data with thin plate smoothing splines - part II: Analysis of topographic dependence, Journal of Geographic Information Systems 9: 385-403.

Isaak, E. H.; Srivastva, R. M. 1989. An introduction to applied geostatistics. Oxford University Press. 592 p.

Jalali, M. 2007. Spatial variability in potassium release among calcareous soils of western Iran, Geoderma 140(1-2): 4251. doi:10.1016/j.geoderma.2007.03.013

Johnson, R. M.; Warburton, J. 2002. Flooding and Geomorphic impacts in a mountain torrent: raise beck, central lake district, England, Earth Surface Processes and Landforms 27(9): 945-969. doi:10.1002/esp.386

Jones, T. A.; Ma, Y. Z. 2001. Geologic characteristics of HoleEffect variograms calculated from lithology - indicator variables, Matematical Geology 33(5): 615-629. doi: 10.1023/A:1011048913041

Karl, T. R.; Knight, R. W. 1998. Secular trends of precipitation, amount, frequency, and intensity in the United States, $B u O$ letin of the American Meteorology Society 79(2): 231-241. doi:10.1175/1520-0477(1998)079<0231:STOPAF $>2.0 . C O ; 2$

Kieffer Weisse, A.; Bois, Ph. 2001. Topographic effects on statistical characteristics of heavy rainfall and mapping in French Alps, Journal of Applied Meteorology 40(4): $720-740$. TEOSCO $>2.0 . \mathrm{CO} ; 2$

Kumar, A.; Maroju, S.; Bhat, A. 2007. Application of ArcGIS geostatistical analyst for interpolating environmental data from observations, Environmental Progress 26(3): 220225. doi:10.1002/ep.10223

Liu, X. M.; Xu, J. M.; Zhang, M. K.; Huang, J. H.; Yu, X. F. 2004. Application of geostatistics and GIS technique to characterize spatial variabilities of bioavailable micronutrients in paddy soils, Environmental Geology 46(2): 189194. doi:10.1007/s00254-004-1025-0

Llasat, M. E.; Rigo, T.; Barriendos, M. 2003. The "Montserrat2000 " flash flood event: a comparison with the floods that have occurred in the Northeastern Iberian peninsula since $14^{\text {th }}$ century, International Journal of Climatology 23(4): 453-469. doi:10.1002/joc. 888

Lu, P.; Su, Y.; Niu, Z.; Wu, J. 2007. Geostatistical analysis and risk assessment on soil total nitrogen and soil phosphorous in Dongting lake plain area, China, Journal of EnvL ronmental Quality 36(4): 935-942. doi:10.2134/jeq2006.0184
Luo, W.; Taylor, M. C.; Parker, S. R. 2008. A comparison of spatial interpolation methods to estimate continuous wind speed surfaces using irregularity distributed data from England and Wales, International Journal of Climatology 28(7): 947-959. doi:10.1002/joc.1583

McGrath, D.; Zhang, C.; Carton, O. T. 2004. Geostatistical analysis and hazard assessment on soil lead on Sivermines area, Ireland, Environmental Pollution 127(2): 239-248. doi:10.1016/j.envpol.2003.07.002

Minder, J. R.; Durran, D. R.; Roe, G. H.; Anders, A. M. 2008. The climatology of small scale orographic precipitation over the Olympic mountains: Patterns and processes, Quartely Journal of the Royal Meteorological Society 134(633): 817-839. doi:10.1002/qj.258

Morata, A.; Luna, M. Y.; Martin, M. L.; Sotillo, M. G.; Valero, F. 2008. Iberian autumnal precipitation characterization through observed, simulated and reanalyzed data, $A G \square$ vances in Geosciences 16: 49-54. doi:10.5194/adgeo-16-49-2008

Muñoz-Diaz, D.; Rodrigo, F. S. 2003. Effects of the North Atlantic Oscillation on the probability for climate categories of local monthly rainfall in southern of Spain, InteU $\square$ national Journal of Climatology 23(4): 381-397. doi:10.1002/joc.886

Nalder, I. A.; Wein, R. W. 1998. Spatial interpolation of climatic normals: Test of a new method in the Canadian boreal forest, Agric. Forest Meteorol. 92(4): 211-225. doi:10.1016/S0168-1923(98)00102-6

Okonski, B. 2007. Hydrological response to land use changes in Central European lowland forest catchments, Journal of Environmental Engineering and Landscape Management 15(1): 3-13.

Pavan, V.; Tomozeiu, R.; Cacciamani, C.; Di Lorenzo, M. 2008. Daily precipitation observations over EmiliaRomagna: mean values and extremes, International Journal of Climatology 28(15): 2065-2079. doi:10.1002/joc.1694

Pereira, P.; Morais, L.; Úbeda, X.; López-Bustins, J. A. 2008. Variabilidad de los extremos de precipitación en Portugal durnate la segunda mitad del siglo XX, in J. S. Rodriguez; M. Brunet and E. Aguilar (Eds.). Cambio climático regiR nal y sus impactos, Publicaciones de la Asociación EspD ñola de Climatologia (AEC). Serie A, 6: 425-435.

Robinson, T. P.; Metternicht, G. 2006. Testing the performance of spatial interpolation techniques for mapping soil properties, Computers and Electronics in Agriculture 50(2): 97-108. doi:10.1016/j.compag.2005.07.003

Rodrigo, F. S.; Esteban-Parra, M. J.; Pozo-Vázquez, D.; CastroDiez, Y. 2000. Rainfall variability in southern Spain on decadal to centennial times series, International Journal of Climatology 20(7): 721-732. doi:10.1002/10970088(20000615)20:7<721::AID-JOC520>3.0.CO;2-Q

Rodríguez-Puebla, C.; Encinas, A. H.; Sáenz, J. 2001. Winter precipitation over the Iberian Peninsula and it's relationship to circulation indices, Hydrology and Earth System Sciences 5: 233-244. doi:10.5194/hess-5-233-2001

Romero, R.; Martín, A.; Homar, V.; Alonso, S.; Ramis, C. 2006. Predictability of prototype flash flood events in the Western Mediterranean under uncertainties of precursor upper-level disturbance, Advances in Geosciences 7: 5563. doi:10.5194/nhess-5-505-2005

Santos, J. A.; Corte-Real, J.; Leite, S. M. 2005. Weather regimes and their connection to the winter rainfall in Portugal, International Journal of Climatology 25(1): 33-50. doi:10.1002/joc.1101 
Shapiro, S.; Wilk, M. 1965. An analysis of variance test for normality, Biometrika 52(3-4): 591-611.

Smith, M. J.; Goodchild, M. F.; Longley, P. A. 2009. GeospD tial Analysis. A compreensive guide to principles tecK $\mathrm{C}$ niques and software tools. Troubador Publishing, Leicester. 394 p.

Stuart, N.; Jarvis, C. H. 2004. Estimating daily precipitation for England and Wales using splines with collateral topographic and radar datasets, GIS and Remote Sensing in Hydrology 289: 378-384.

Subyani, A. M. 2004. Geostatistical study of annual and seasonal mean rainfall patterns in southwest Saudi Arabia, $H \backslash$, drological Sciences Journal 49(5): 803-817.

Surda, P.; Simonides, I.; Antal, J. 2007. A determination of area od potential erosion by geographic information systems, Journal of Environmental Engineering and Landscape Management 15(3): 144-152.

Tait, A.; Henderson, R.; Turner, R.; Zheng, X. 2006. Thin plate smoothing spline interpolation of daily rainfall for New Zealand using a climatological rainfall surface, InternD $\mathrm{Q}$ tional Journal of Climatology 26(14): 2097-2115. doi:10.1002/joc. 1350

Talmi, A.; Gilat, G. 1977. Method for smooth approximation of data, Journal of Computational Physics 23(2): 93-123. doi:10.1016/0021-9991(77)90115-2

Tildes Gomes, P. 1998. Variabilidade da precipitaçao em Portugal e relaçoes com os sistema oceano-atmosfera no Atlântico Norte, Finisterra 33(66): 77-89.

Trigo, R. M.; DaCamara, C. C. 2000. Circulation weather types and their influence on the precipitation regime in Portugal, International Journal of Climatology 20(13): 1559-1581. doi:10.1002/1097-0088(20001115)20:13<1559::AIDJOC555>3.0.CO;2-5

Valero, F.; Luna, M. Y.; Martin, M. L.; Morata, A.; GonzalezRouco, F. 2004. Coupled modes of large-scale climatic variables and regional precipitation in the Western Medi- terranean in autumn, Climate Dynamics 22(2-3): 307323. doi:10.1007/s00382-003-0382-9

Valero, F.; Martín, M. L.; Sotillo, M. G.; Morata, A.; Luna, M. Y. 2009. Characterization of the autumn Iberian precipitation from long-term datasets: comparison between observed and hindcast data, International Journal of Climatology 29(4): 527-541. doi:10.1002/joc.1726

Vicente-Serrano, S. M.; Saz-Sánchez, M. A.; Cuadrat, J. M. 2003. Comparative analysis of interpolation methods in the middle Ebro Valley (Spain): application to annual precipitation and temperature, Climate Research 24(2): 161180. doi:10.3354/cr024161

Wang, G.; Schimel, D. 2003. Climate change, Climate modes, and climate impacts, Annu. Rev. Environ. Resources 28: $1-28$.

Webster, R.; Oliver, M. A. 2007. Geostatistics for environmeQ tal scientists. Wiley Interscience. $2^{\text {nd }}$ ed. London. $330 \mathrm{p}$.

Wenngartner, R.; Barben, B.; Sperafico, M. 2003. Floods in mountain areas - an overview based on examples from Switzerland, Journal of Hydrology 282(1-4): 10-24. doi:10.1016/S0022-1694(03)00249-X

Wijngard, J. B.; Klein Tank, A. M. G.; Koennen, G. P. 2003. Homogeneity of $20^{\text {th }}$ century European daily temperature and precipitation, International Journal of Climatology 23(6): 679-692. doi:10.1002/joc.906

Yilmaz, H. M. 2007.The effect of interpolation methods in surface definition: an experimental study, Earth Surface and Landforms 32(9): 1346-1361. doi: 10.1002/esp.1473

Zêzere, J. L.; Trigo, R. M.; Trigo, I. F. 2005. Shallow and deep landslides induced by rainfall in Lisbon region (Portugal): assessments of relationships with NAO, Natural Hazards and Earth System Sciences 5: 331-344. doi:10.5194/nhess-5-331-2005

\section{GAUSIŲ KRITULIŲ PASISKIRSTYMO POVEIKIO PAVOJINGOSE KALNŲ VIETOVĖSE MODELIAVIMAS. PAGALBA PLANUOJANT KRAŠTOVAIZDI A PLINKOS VALDYMA}

\section{P. Pereira, M. Oliva, E. Baltrìaitè}

\section{Santrauka}

Gauș̄s krituliai, ypač būingi Viduržemio jūos regionui , gali kelti rimtų pavojų aplinkai, lemti katastrofas. Kritulių poveikio zona ypačišsipleča rudens laikotarpiu, t. y. rugsథ், spalio ir lapkriơ̌o (RSL) ménesiais , neretai patiriama didelių ekonominių nuostolių žissta ar kitaip nukenđ̌a žmonṡ. S taț̄s kalnųšlaitai sustiprina gausių kritulių poveikị Kalnuotose vietovக̉e kritulių kiekio stebğimo stođ̆ų nedaug, jos toli viena nuo kitos, todæ labai aktualu turæi žemłapi us, tiksliai nusakanđ̆us gausiųkrituliųpasiskirstymą Kalnuotose vietovėe krituliųpobūdis skirtingu ats tumu gali bữi skirtingas, krituliųkiekn̨umatyti sunkiau, tačau tai itin svarbu. Tiksliau numatant vietoves, kur iškrinta daugiau kritulių galima tikslingiau planuoti žemævarką, išvengti staigių potvynių nuošliaužų ir dirvožemio erozijos . Tyrimo tikslas buvo patikrinti kelis gerai žinomus interpoliacijos metodus - Inverse Distance Weight (IDW) su 1-5 svertinėnis vertinis , Local Polynomial (LP), Radial Basis (RBS), ypač Spline With Tension (SPT), Thin Plate Spline (TPS), - bei Kriging technikas ir Ordinary Kriging $(O K)$ bei Ordinary CoKriging $(C O K)$ metodus, siekiant parinkti tiksliausią kuris leistų interp oliuoti gausius (95\%) kritulius RSL møંesiais kalnuotoje Portugalijos teritorijoje. Nustatyta, kad kritulių kiekis didg̣a didg்ant altitudei . Reikšmingi kritulių skirtumai nustatyti stotyse, esančose skirtinguose aukšđ̆uose virš jūros lygio. Šis santykis pastebæas visomis kryptimis apskaič̉uotose pusin è e variogramose. Jose išsiskiria dvi teritorijos, kurių P95 vertè didžiausios, ir akivaizdi sæ̨aja su didelèn is altitudėnis . Pirmoji teritorija 12,19 km, o antroji $23,57 \mathrm{~km}$ aukštyje. Didžiausios P95 vertès pietryợuir šiaure் rytų kryptimis, mažiausios - šiaurè vakarų kryptimi, kur altitudes mažos, ir šiauré rytų teritorijos kampe de lietaus „šešæ io“ efekto. Tiksliai numatyti krituliųpobū ị kalnuotose teritorijose apsunkina duomenųtrükumas ir sudđinga topografijostąka krituliams . Rezultatai ypačparankūs planuojant ir valdant dažniems ir gausiems krituliams jautrias teritorijas.

Reikšminiai žodžiai: gausūs krituliai, pavojus aplinkai, Viduržemio regionas, rugsø̣is, spalis, lapkritis (RSL), kalnuotos

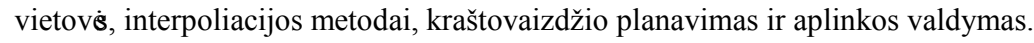




\title{
МОДЕЛИРОВАНИЕ ВЛИЯНИЯ РАСПРЕДЕЛЕНИЯ ОБИЛЬНЫХ ОСАДКОВ В ОПАСНЫХ ГОРНЫХ МЕСТНОСТЯХ. ПОМОЩЬ В ПЛАНИРОВАНИИ ЛАНДШАФТА И УПРАВЛЕНИИ ОКРУЖАЮЩЕЙ СРЕДОЙ
}

\author{
П. Перейра, М. Олива, Э. Балтренайте
}

Резюме

Обильные осадки, особенно характерные для Средиземноморского региона, могут быть опасными для окружающей среды. Зона влияния осадков особенно увеличивается в осенний период - сентябре, октябре и ноябре. Осадки зачастую вызывают большие экономические убытки, гибнут или страдают люди. Влияние обильных осадков усиливают крутые горные склоны. В горных местностях станций наблюдения за количеством осадков немного и расположены они далеко друг от друга, поэтому необходимы карты, на которых было бы точно указано распределение обильных осадков. Характер осадков в горных местностях в зависимости от удаленности может значительно различаться, предвидеть количество осадков чрезвычайно сложно, однако это жизненно необходимо. Зная местности, на которых ожидается большее количество осадков, можно точнее планировать землеустройство, избежать внезапных наводнений, оползней и эрозии почв. Целью исследования было проверить несколько хорошо известных методов интерполяции - Inverse Distance Weight (IDW) с 1-5 значениями весомостей, Local Polynomial (LP), Radial Basis (RBS), особенно Spline With Tension (SPT), Thin Plate Spline (TPS), а также технику Kriging, методы Ordinary Kriging $(O K)$ и Ordinary CoKriging $(C O K)$ с целью выявить наиболее точный, с помощью которого можно было бы интерполировать обильные (95\%) осенние осадки в горных местностях Португалии. Установлено, что количество осадков увеличивается с увеличением амплитуды. Значительная разница в количестве осадков выявлена на станциях, находящихся на разной высоте от уровня моря. Это соотношение замечено на всех направлениях рассчитанных полувариограмм. На них выделяются две территории, на которых значения Р95 наиболее велики и очевидна связь с большими амплитудами. Первая территория находится на высоте 12,19 км, вторая - 23,57 км. Наибольшие значения Р95 отмечены в юго-восточном и северо-восточном, наименьшие - северо-западном направлениях, где амплитуды малы, и в углу северо-восточной территории из-за эффекта «тени» дождя. Точнее предвидеть характер осадков в горных местностях представляется затруднительным из-за недостатка данных и сложного влияния на осадки топографии. Результаты исследования окажутся особенно полезными при планировании и управлении территориями, подвергаемыми частым и обильным осадкам.

Ключевые слова: обильные осадки, опасность для окружающей среды, Средиземноморский регион, осенний период, горная местность, методы интерполяции, планирование ландшафта и управление окружающей средой.

Paulo PEREIRA. M.Sc is PhD student and researcher of the Mediterranean Environment Research Group (GRAM) of the University of Barcelona and of the Department of Environmental Protection of Vilnius Gediminas Technical University. Membership: European Geosciences Union, World Association of Soil and Water Conservation, Spanish Fire Network. Research Interests: Fire effects on soil and water chemistry, Heavy metals on soils and water, Impacts of agriculture in soil erosion, Climate change and behavior of extremes, sustainable development and environmental modelling.

Marc OLIVA is a postdoc researcher at the Centro de Estudos Geográficos of the University of Lisbon. PhD in Physical Geography at the University of Barcelona (2009). His dissertation focused on the present and past dynamics of periglacial processes in Sierra Nevada (Southern Spain). He has reconstructed the palaeoecological evolution in the present periglacial belt of this high semiarid Mediterranean massif studying two sedimentary records: solifluction lobes and mountain lakes. Both archives suggest important landscape changes in Sierra Nevada during the Mid-Late Holocene driven by climate variability. Since December 2009 he is researcher at the Antarctic Environments and Climate Change Research Group (AntECC). His ongoing research is focused on the study of the key factors controlling present and past slope processes in permafrost environments from polar areas (Antarctica, Svalbard).

Edita BALTRÉNAITÉ. Dr, Associate Professor at the Department of Environmental Protection, Vilnius Gediminas Technical University. She gained her Environmental Engineering and Landscape Management PhD in 2007 from Vilnius Gediminas Technical University. Publications: author/co-author of $\sim 25$ scientific papers. Research interests: metal uptake and translocation in higher plants, biogeochemistry, modeling of environmental processes. 